\title{
THE EARLIEST OSTRACODA RECORD FROM BRAZIL: VILA MARIA FORMATION, RIO IVAÍ GROUP, PARANÁ BASIN, CENTRAL BRAZIL
}

\author{
RODRIGO RODRIGUES ADÔRNO \\ Serviço Geológico do Brasil, CPRM, 76801-581, Porto Velho, RO, Brazil.rodrigo-afonso@cprm.gov.br \\ DERMEVAL APARECIDO DO CARMO \\ Laboratório de Micropaleontologia, Instituto de Geociências, Universidade de Brasília, Campus Darcy Ribeiro, \\ 70910-900, Brasília, DF, Brazil.derme@unb.br \\ MARIA JOSE SALAS \\ Universidad Nacional de Córdoba, CIPAL, CICTERRA-CONICET, Av. Vélez Sarsfield 1611, X5016GCA, \\ Córdoba, Argentina.mjsalas@unc.edu.ar \\ CAROLINA ZABINI \\ Departamento de Geologia e Recursos Naturais, Instituto de Geociências, Universidade Estadual de Campinas, \\ 13083-870, Campinas, SP, Brazil. carolinaz@ige.unicamp.br \\ MARIO LUIS ASSINE \\ Departamento de Geologia Aplicada, Instituto de Geociências, Universidade Estadual Paulista, \\ Campus de Rio Claro, 13506-900, Rio Claro, SP, Brazil. assine@rc.unesp.br
}

\begin{abstract}
Two species of Ostracoda are described for the first time from the parastratotype-section of Vila Maria Formation; this section is $30 \mathrm{~m}$ thick, located on the northern border of the Paraná Basin. The Vila Maria Formation records the Upper Ordovician-Lower Silurian boundary of the Paraná Basin in Bom Jardim de Goiás, State of Goiás, central Brazil. The new species represents the earliest Ostracoda occurrence from Brazilian strata. Delicate internal and external molds of isolated valves are abundant in the basal portion of the parastratotype-section of Vila Maria Formation. This interval comprises black shales that record post-glacial marine transgression, overlapping the Upper Ordovician glacial sequence of the Iapó Formation. The paleogeographic reconstruction indicates that deposition of the basal portion of the Vila Maria Formation took place in high-latitude, cool water conditions at the margin of Gondwana, under similar environmental conditions to the Djeffara Formation in the Ghadames Basin and the Tichitt Group in the Taoudeni Basin, both in the Northern Africa.
\end{abstract}

Key words: Ostracoda, Ordovician, Paraná Basin.

RESUMO - Duas espécies de Ostracoda têm ocorrências inéditas descritas a partir da seção-tipo suplementar da Formação Vila Maria, seção que tem 30 m de espessura, localizada na borda norte da Bacia do Paraná. A Formação Vila Maria está posicionada no limite Ordoviciano Superior-Siluriano inferior da Bacia do Paraná na região de Bom Jardim de Goiás, Estado de Goiás, Brasil central. As novas espécies descritas representam a ocorrência mais antiga de Ostracoda de estratos brasileiros. Moldes internos e externos de valvas isoladas são abundantes na porção basal da seção-tipo suplementar da Formação Vila Maria. Este intervalo é constituído por folhelhos pretos representando a transgressão marinha pós-glacial, sobrepostos aos diamictitos da Formação Iapó, que representa a sequência glacial do Neordoviciano na Bacia do Paraná. A reconstrução paleogeográfica indica que a deposição da porção basal da Formação Vila Maria ocorreu sob condições de altas latitudes e águas frias na margem de Gondwana, onde atualmente se localiza a América do Sul, sob condições semelhantes àquelas das Formações Djeffara na Bacia de Ghadames e Tichitt Group na Bacia do Taoudeni onde atualmente se localiza a porção norte da África.

Palavras-chave: Ostracoda, Ordoviciano, Bacia do Paraná.

\section{INTRODUCTION}

Worldwide the late Ordovician/early Silurian glaciation has been studied mostly because of its importance for hydrocarbon exploration, especially on northern Gondwana (Rubino et al., 2003; El-Ghali, 2005). Additionally, the Ordovician/Silurian boundary is the aim of paleoecological studies in respect to the great extinction event related to this glaciation period (Rong \& Harper, 1988). According to El-Ghali (2005) the late Ordovician ice sheet had its center over central Africa and its borders expanded to the nearby continents during early Hirnantian. At Libya and Mauritania outcrops, there are 
glacial cycles preserved and the glacial succession represents a fully marine paleoenvironment (Rubino et al., 2003). The authors also state that the transgression occurred during the latest Ordovician, and the Silurian deposits probably record the final melting of the glacier.

It is very interesting to note that these sequences are very similar, being composed of sandy deposits followed by silty/shaly deposits in several Gondwana basins like Paraná, Parnaíba, Jatobá and Amazonas Basins in Brazil, Taoudeni Basin in West African Craton and Murzuq Basin in Libya (Gray et al., 1985; Assine et al., 1994; Rubino et al., 2003; El-Ghali, 2005; Ghienne, 2003; Benedetto et al., 2013).

According to Assine et al. (1994) Brazilian midpaleozoic strata where recognized only on 1970 decade, by the presence of Arthrophycus alleghaniensis (Harlan, 1831) Hall, 1852, at the northern border of the Paraná Basin. Since this discovery, several papers have discussed the relations among the different stratigraphy units (Ordovician, Silurian, Devonian), based not only on surface outcrops, but especially using borehole data (Assine et al., 1994). The Vila Maria Formation, Rio Ivaí Group, Paraná Basin, Brazil, was initially suggested as a stratigraphic unit by Faria \& Reis Neto (1978) and it was finally proposed as a formal stratigraphic unit by Faria (1982).

After the formalization of the Vila Maria Formation, several authors attempted to divide this formation as well as to determine its boundaries (Zalán et al., 1987; Assine \& Soares, 1989; Assine et al., 1994). Zalán et al. (1987) proposed a tripartite model where the deposition of the Paraná Basin began with the Rio Ivaí Formation, followed by the Vila Maria and Furnas formations with gradual contact between each other (Figure 1A). Assine et al. (1994), using well logs and gamma ray logs, created the modern concept used in this paper of the Rio Ivaí Group consisting of the Alto Garças Formation, followed by the Iapó Formation (Late Ordovician glaciation) and finally by the Vila Maria Formation (Figure 1B).

According to Assine et al. (1994) the shales of the Vila Maria Formation were deposited during the early Silurian (Llandovery), which is in accordance with some publications that are based on fossil occurrences in Vila Maria Formation (Popp et al., 1981; Burjack \& Popp, 1981; Faria, 1982; Gray et al., 1985; Borghi et al., 1996). Nonetheless, Adôrno (2014) suggests a Late Ordovician age for the basal shales of the Vila Maria Formation based on a preliminary study on Ostracoda. The only numerical dating of the Vila Maria Formation was performed by Mizusaki et al. (2002) coming from black shale that crops out on Três Barras Farm, a location also studied by Gray et al. (1985). This dating indicated an age of $435.9 \pm 7.8 \mathrm{Ma}$ according to the $\mathrm{Rb} /$ Sr method, with uncertainties related to isotopic homogenization during diagenesis and may, therefore represent diagenetic events younger than the deposition age of these shales.

The Ostracoda dating herein presented complies with the preliminarily dating presented by Adôrno (2014) (Figure $1 \mathrm{C})$, in addition to the lithostratigraphic correlation between Iapó glaciation and other Late Ordovician glaciations in

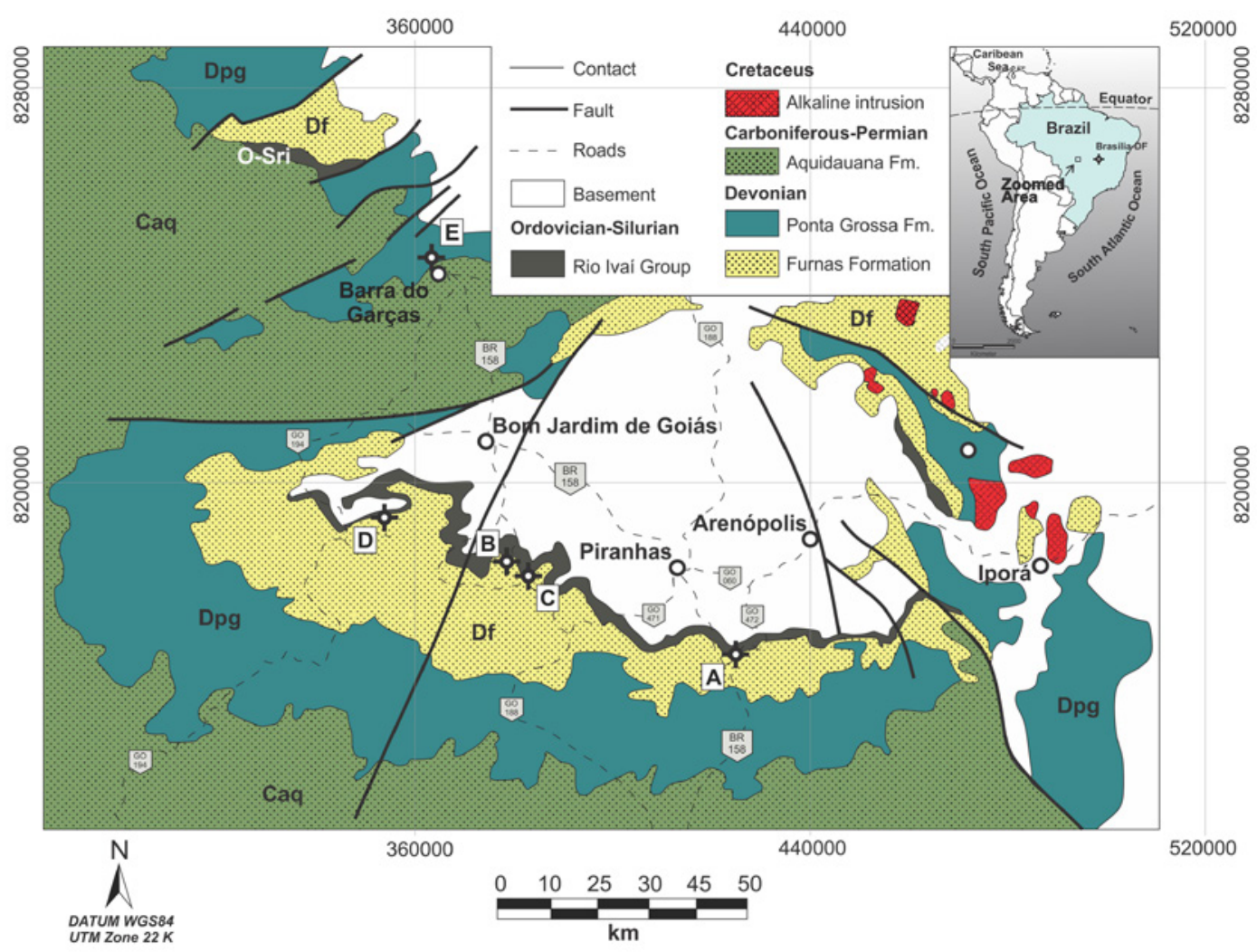

Figure 1. Geological map of the studied area showing the Rio Ivaí Group, southwestern Goiás and southeastern Mato Grosso states, central Brazil (Adapted from Alvarenga et al., 1998). O-Sri, Rio Ivaí Group, Ordovician-Silurian; Df, Furnas Formation, Devonian; Dpg, Ponta Grossa Formation Devonian; Caq, Aquidauana Formation, Carboniferous. A, Type-section of Vila Maria Formation; B, Parastratotype-section of Vila Maria Formation; C, Três Barras Farm outcrop; D, Perdizes waterfall outcrop; E, COHAB neighborhood outcrop. 


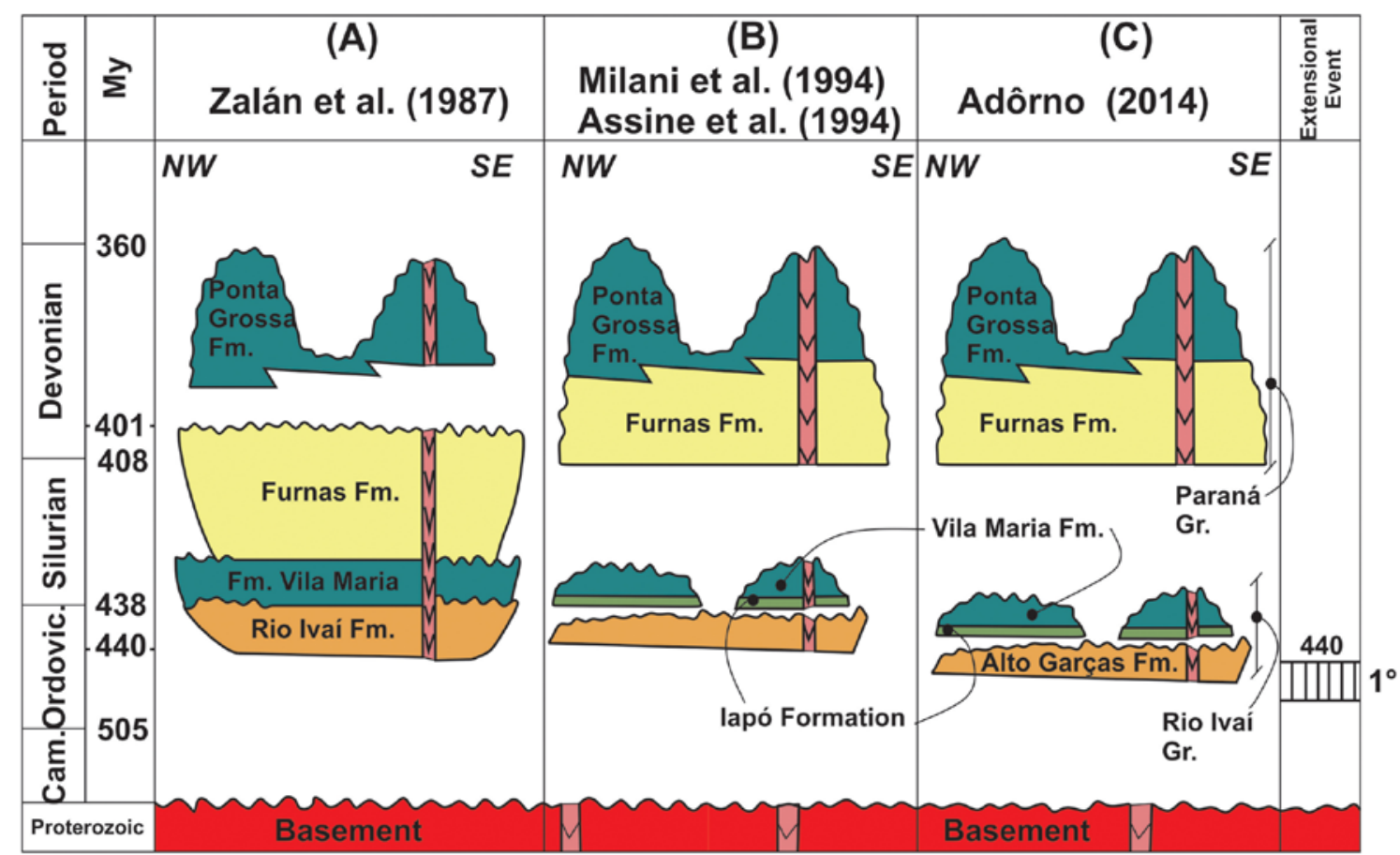

Figure 2. The evolution of chronostratigraphy of Rio Ivaí and Paraná Group. A, The known "Tripartite model of the Silurian", showing concordant contacts between Rio Ivaí, Vila Maria and Furnas formations; B, the Rio Ivaí Group concept; C, new dating based on paleontological data repositioning the basal portion of Vila Maria Formation to Upper Ordovician.

Gondwana basins, as is discussed in the paleobiogeographic considerations section. This paper aims to present new descriptions and distributions of the two oldest Ostracoda species of the Brazil, recorded in State of Goiás, Rio Ivaí Group, Vila Maria Formation, Paraná Basin; also, are presented a detailed lithostratigraphic column of the Vila Maria Formation of the parastratotype-section, and a map with an updated UTM position of the main outcrops of the Rio Ivaí Group in the northern border of the Paraná Basin. Additionally, this Ostracoda study, integrated with the previous fossiliferous occurrences in the Vila Maria Formation, provides a new chronostratigraphic evolution for the Ordovician-Silurian interval of the Paraná Basin, allowing correlations with other basins in Gondwanaland.

\section{GEOLOGICAL SETTING AND PROVENANCE OF THE MATERIAL}

The vast Paraná Basin extends through southern to central Brazil, Paraguay, Uruguay and northern Argentina (Milani et al., 2007). The oldest sequence deposited in southern and central-western Brazil is represented by the sedimentary package of the Rio Ivaí Group assigned to the Upper Ordovician to Llandovery interval. This group is composed of three formations in ascending order: Alto Garças, Iapó and Vila Maria (Assine et al., 1994; Milani et al., 2007). The Alto Garças Formation consists of thick conglomeratic sandstones deposited directly on the crystalline basement. The Neoproterozoic crystalline basement comprises rhyolite, andesite and metapelitic rocks of the Cuiabá Group in the parastratotype-section area (Faria, 1982).
The Iapó Formation consists of glaciogenic diamictites, shale with dropstones and lenses of siltstone (Milani et al., 1994; Milani et al., 2007). Finally, the diamictites of the Iapó Formation are overlain by the marine deposits of the Vila Maria Formation. The fossiliferous shale of the Vila Maria Formation represents a remarkable guide-layer in the Rio Ivaí Group (Milani et al., 2007). The fossiliferous shale and siltstone of the Vila Maria Formation are generally red to yellow, and with ferruginous aspect when weathered, however, locally, when they are fresh, can be dark gray to black (Faria, 1982; Milani et al., 1994; Milani et al., 2007). The studied ostracods came mainly from the basal levels of the Vila Maria Formation in its parastratotype-section located on Boa Vista Farm, Bom Jardim de Goiás County, State of Goiás, central Brazil (Figure 2).

The parastratotype-section is approximately 30 meters thick, comprising the glaciogenic diamictite of the Iapó Formation, which is deposited directly above the Neoproterozoic crystalline basement by an erosional unconformity (Figure 3). Immediately above the Iapó Formation, with gradual contact, were deposited $11 \mathrm{~m}$ of black fossiliferous shales of the Vila Maria Formation, where the ostracods studied in this paper come from (Figure 3). The ostracods in the basal portion of the Vila Maria Formation are associated with Bivalve Nuculites? sp. and Gastropoda Bucanella? sp. and inarticulate Brachiopoda Kosoidea sp. (Zabini et al., 2016). The intermediate portion of the Vila Maria Formation is approximately four meters thick, composed of reddish siltstone with only Kosoidea sp. occurrences (Figure 3). The upper portion of the Vila Maria Formation has approximately seven meters thick, composed of siltstones and sandstones with Arthrophycus alleghaniensis 


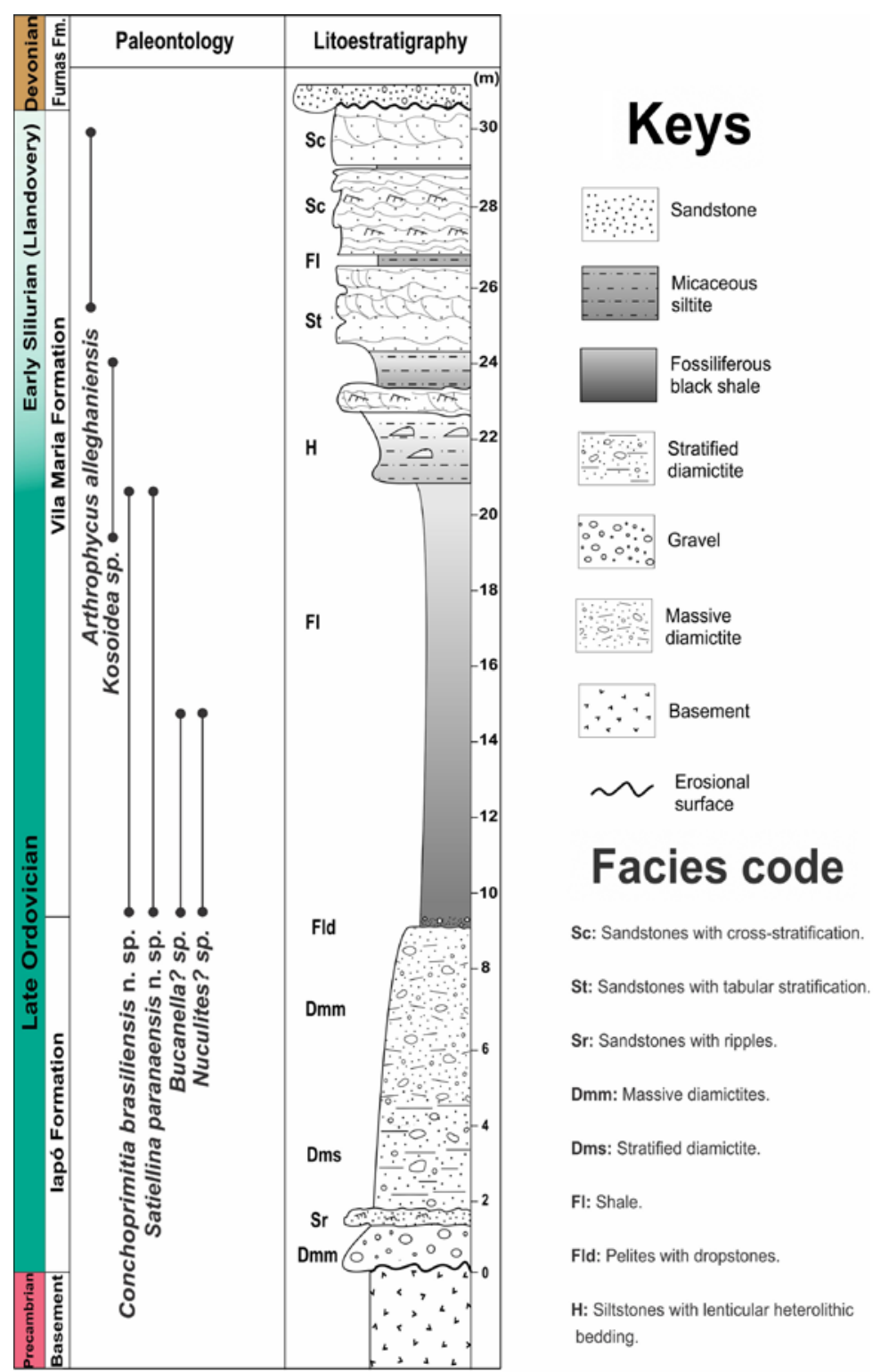

Figure 3. Stratigraphic log showing the ranges of fossiliferous occurrences in the parastratotype-section in Aldeia creek, Bela Vista Farm, Bom Jardim de Goiás County, State of Goiás, central Brazil (modified from Adorno, 2014).

(Figure 3). This ichnofossil was previously used to indicate that the whole Vila Maria Formation was deposited during the early Silurian age (Burjack \& Pop, 1981; Faria, 1982; Borghi et al., 1996). It is worth emphasizing that Arthrophycus alleghaniensis is distinctively of Ordovician-Silurian (?Early Devonian) age (Kumpulainen et al., 2006), and has a worldwide distribution as shown in the Biostratigraphic and Paleogeographic Considerations part of the present paper.

\section{MATERIAL AND METHODS}

\section{Techniques of study}

Rock samples of the studied material were collected during successive field expeditions performed by the first author during his Master's dissertation. Sampling and surveying of the stratigraphic log with positioning of fossils recovered from the parastratotype-section of the Vila Maria Formation were performed during the fieldtrip. Ostracods from the Vila Maria Formation appear only as internal and external molds in shale samples. These ostracods have been prepared mechanically using a 'vibro-tool' and fine needles; the external molds have been cast using latex rubber at the CICTERRA-CONICET/ Universidad Nacional de Córdoba, Argentina. The specimens were covered with a thin layer of carbon or gold and were studied by means of Scanning Electron Microscopy (SEM) at the Institute of Geosciences, University of Brasilia, Brazil.

\section{Taxonomy of Ostracoda}

Two new species of Ostracoda are identified. The taxonomic classification adopted in this article follows that of Mohibullah et al. (2014) and references included. The terms used for morphologic features are based on Moore \& Pitrat (1961) and Vannier et al. (1989). Specimens considered in this article are housed in the collections of the Museum of Geosciences, 
Laboratory of Micropaleontology, Institute of Geosciences, University of Brasília, Brazil, identified with the prefix CP-.

Abbreviations: L, maximum length; $\mathbf{H}$, maximum height; L:H, maximum length/maximum height ratio; L1-L2 lobes, anterior and posterior one; $\mathbf{S 2}$, adductorial sulci.

\section{SYSTEMATIC PALEONTOLOGY}

Class OSTRACODA Latreille, 1802

Subclass PODOCOPA Sars, 1866

Order BEYRICHIOCOPIDA Pokorný, 1954

Suborder BINODICOPINA Schallreuter, 1972

Superfamily DREPANELLOIDEA Ulrich \& Bassler, 1923 Family INCERTAE

Satiellina Vannier, 1986

Type-species. Bollia delgadoi Vannier, 1983.

Satiellina paranaensis Adôrno \& Salas n. sp. (Figures 4A-F)

2014 Satiellina jamairensis Vannier, 1986; Adôrno, 2014.

Holotype. Right valve (CP-634), external view of external mold (Figure 4A) and the latex cast of the mold (Figure 4B). Paratypes. Right valve (CP-645), internal mold (Figure 4C); left valve (CP-637) (Figure 4D); left valve (CP-643) (Figure 4E); left valve CP-651 (Figure 4F).
Type locality. Parastratotype-section of Vila Maria Formation, Aldea Creek, Boa Vista Farm, Bom Jardim de Goiás County, State of Goiás, central Brazil northern flank of the Paraná Basin, Brazil. Coordinates: UTM, Zone 22K. 382963E, 8181666N (Figure 2).

Type horizon. Black shales at the lower portion of the Vila Maria Formation, Rio Ivaí Group. Upper Ordovician (Figure 3). Etymology. It refers to the Paraná Basin, type locality of the species.

Diagnosis. Satiellina species without ventral connections of lobes in the external side of valves, the connection is poorly developed in the internal molds. Lateral surface of valves punctuate. Marginal ridge along free edge.

Description. Valves amplete and subelliptical in outline measuring between 950 to $1380 \mu \mathrm{m}$ length and 699 to 1100 $\mu m$ height. Cardinal angles are obtuse and well defined. Dorsal margin straight and shorter than the maximum length of valves. Anterior, posterior and ventral margins evenly rounded. The valves bear two well-developed lobes towards the anterior sector. The lobes are long, reach the ventral half of valves and the dorsal margin, in some specimens overreach it. L1 is near the anterior margin, shorter than L2 and slightly swollen in its median sector. L2 is longer, crescent-like towards the anterior margin, and wider in its ventral half. Lobes are linked ventrally almost imperceptibly; the union is visible in the internal molds by the presence of a shallow groove. In the external molds the union is lacking. S2 is narrow, with its margin parallels; its ventral end is poorly defined. Marginal surface convex. Lateral surface punctuate. Valves with a marginal ridge along all the free edge.

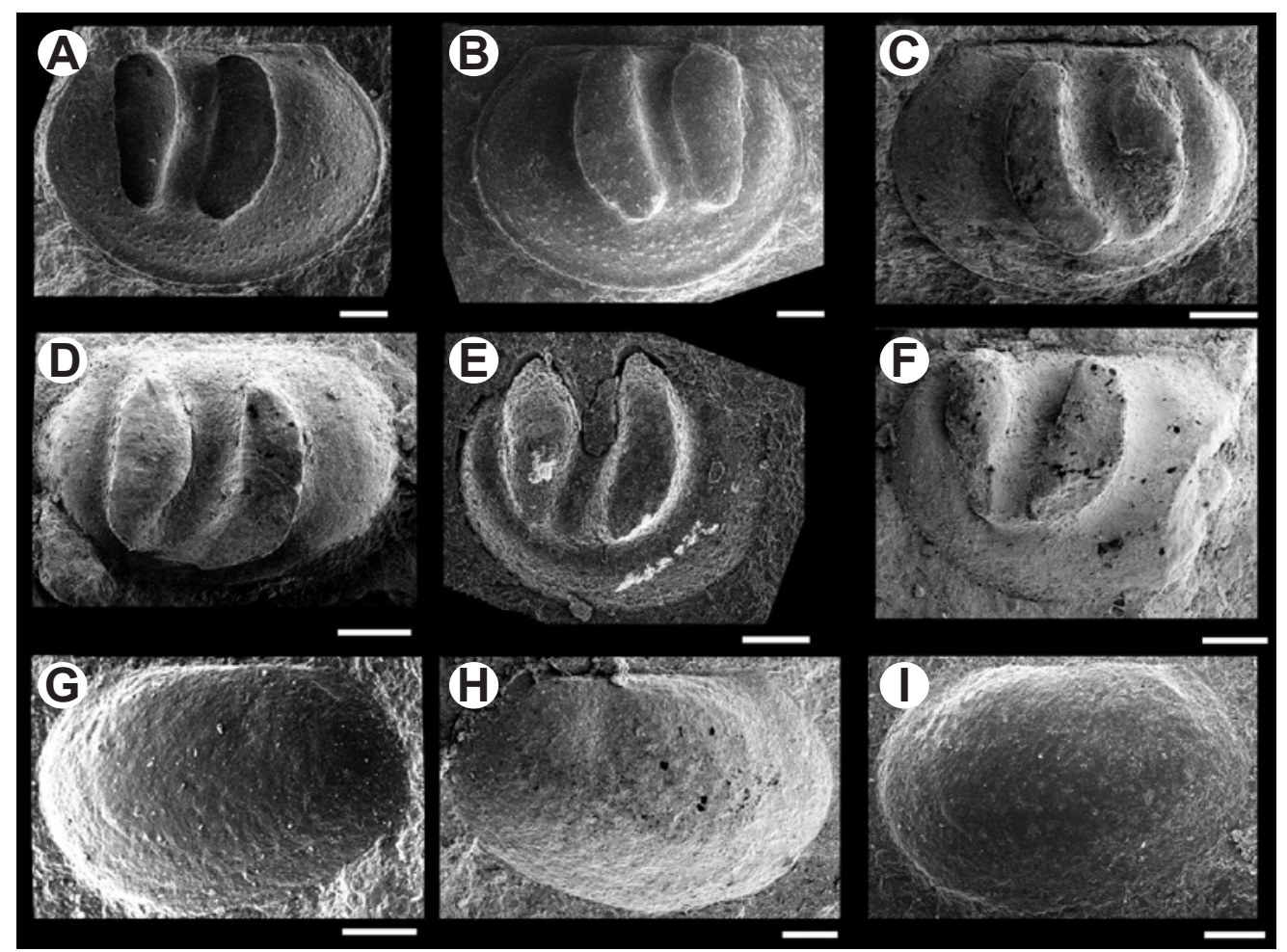

Figure 4. A-F, Satiellina paranaensis n. sp. A-B, CP-634, right valve, lateral view; A, holotype external mold; B, latex cast of the external mold; C, CP-645 paratype, right valve, lateral view of an internal mold; D-F, left valves, lateral views of internal molds; D, CP-637; E, CP-643; F, CP651. G-I, Conchoprimitia brasiliensis n. sp; G, Holotype CP-631, right valve, lateral view of an external mold; H, CP-649, left valve, lateral view of an internal mold; I, CP-635, right valve, lateral view of an internal mold. Scale bars $=200 \mu \mathrm{m}$. 
Material. Nearly twenty external and internal molds of valves. Illustrated specimens are CP-634, holotype (Figure 4A); CP-634, holotype cast latex (Figure 4B); paratypes: CP645 (Figure 4C); CP-637 (Figure 4D); CP-643 (Figure 4E); CP-651 (Figure 4F); (Table 1).

Remarks. The new species is assigned to Satiellina from the Middle to Upper Ordovician of Ibero-Armorica, North of Africa and Baltic region by the two well developed, elongated and ventrally connected lobes, and by the convex lateral surface without pseudovelum. Originally, Adôrno (2014), in a preliminary work, attributed this material to $S$. jamairiensis Vannier, 1986, from the Djeffara Formation (Upper Ordovician) of Libya. Both species are similar in the outline of the valves, mean of sizes $1200 \mu \mathrm{m}$ length per 900 $\mu \mathrm{m}$ height, in the posterior extralobular surface of valves and in the shape of L1. However, the new material differs in L2 which is slightly longer and narrower, and mainly in the ventral connection of lobes, which is inconspicuous, and only visible in the internal mold. It is absent in the exterior side of valves. The last feature differentiates the new species of all known species of the genus. Another distinctive characteristic of Satiellina paranaensis $\mathrm{n}$. $\mathrm{sp}$. is the punctate lateral surface of valves. Respect to S. delgadoi (Vannier, 1983), type species of the genus, from the Middle Ordovician of Ibero-America, the new material differs by its shorter and wider lobes and by its poorly defined ventral connection of lobes. In addition $S$. delgadoi bears a very well developed furrow between the lobes and the lateral surface of valves.

Occurrence. Known only from the type locality at the Aldea Creek, Boa Vista Farm, Bom Jardim de Goiás County, State of Goiás, central Brazil.

Suborder ERIDOSTRACINA Adamczak, 1961 Family CONCHOPRIMITIIDAE Henningsmoen, 1953

Conchoprimitia Öpik, 1935

Type-species. Conchoprimitia gammae Öpik, 1935.

Conchoprimitia brasiliensis Adôrno \& Salas n. sp. (Figures 4G-I)

2014 Conchiprimitia sp.; Adôrno, 2014.

Holotype. CP-631, right valve (Figure 4G).

Table 1. Measurements $(\mu \mathrm{m})$ of Satiellina paranaensis $\mathrm{n}$. sp. valves recovered from the parastratotype-section, Aldeia creek, Boa Vista Farm, Bom Jardim de Goiás County, State of Goiás, central Brazil.

\begin{tabular}{cccccc}
\hline Specimen & L & H & L: H & $\begin{array}{c}\text { Illustration } \\
\text { (Figure) }\end{array}$ & View \\
\hline $\begin{array}{c}\text { CP-634 } \\
\text { Holotype }\end{array}$ & 1380 & 1010 & 1,36 & $4 \mathrm{~A}$ & rigth valve \\
CP-637 & 955 & 660 & 1,4 & $4 \mathrm{D}$ & left valve \\
CP-643 & 1210 & 990 & 1,22 & $4 \mathrm{E}$ & left valve \\
CP-645 & 1210 & 880 & 1,37 & $4 \mathrm{C}$ & rigth valve \\
CP-651 & 953 & 699 & 1,36 & 4F & left valve \\
\hline
\end{tabular}

Paratypes. CP-649, internal mold of a left valve (Figure 4H); CP-635, internal mold of a right valve (Figure 4I);

Type locality. Parastratotype-section of Vila Maria Formation, Aldea Creek, Boa Vista Farm, Bom Jardim de Goiás County, State of Goiás, central Brazil northern flank of the Paraná Basin, Brazil. Coordinates: UTM, Zone 22K. 382963E, 8181666N (Figure 2).

Type horizon. Black shales at the lower portion of the Vila Maria Formation, Rio Ivaí Group. Upper Ordovician (Figure 3). Etymology. In reference to the first record of Conchoprimitia in Brazil.

Diagnosis. Elliptical and slightly postplete outline. Well defined and obtuse cardinal angles. Valves with an inconspicuous and rounded pre-adductorial node and a short and narrow sulcus immediately behind it. Lateral surface punctate.

Description. Valves with an elliptical and slightly postplete outline. Dorsal margin straight and extending approximately two-thirds of the maximum length of valves. Greatest length at the mid-height, reaches $1300 \mu \mathrm{m}$. Average $\mathrm{L}: \mathrm{H}=1,5$. Well defined and obtuse, similar between each other, cardinal angles. Ventral and lateral margins rounded, with the posterior one slightly broader than the anterior. Rounded and inconspicuous pre-adductorial node located in the anterodorsal region, near to dorsal margin. Immediately behind the node there is a shallow, short and perpendicular to the dorsal margin adductorial sulcus. Lateral surface punctate. Some valves show possible retention marks (see Figure 4I), however the line could indicate the limit between the lateral and marginal surface or a difference in the preservation. Carapace slightly convex, with the widest sector in the posterior half of valves.

Material. Nearly thirty external and internal molds of valves. Illustrated specimens are CP-631, holotype (Figure 4G); paratypes, CP-649 (Figure 4H); CP-635 (Figure 4I); (Table 2). Discussion. Conchoprimitia is a widespread genus during the Ordovician, characterized by its simple morphology, so numerous species of the genus were defined. This characteristic, with the shortage of the recorded material which is composed by molds, difficult the taxonomic assignation. However, features like the long hinge line, the postplete outline, the convex carapace, the absence of distinct lobes and sulci and the possible retention mark allow the generic assignation to Conchoprimitia. The overlap of the valves is unknown. Although in the last years there have been some partial revisions, the genus requires a comprehensive review. Some examples to mention are Tinn et al. (2010) who revised the Baltic species, grouping them into a polymorphic species C. socialis (Brøgger, 1882) and Lajblova et al. (2014) who revised the species Conchoprimitia? dejvicensis and Conchoprimites osekensis described by Přibyl (1979), considering $C$.? dejvicensis as a growth stages of $C$. osekensis. The study material is also comparable with Orechina Kruta, 1968, from the Ordovician of Bohemia, Baltic region, Poland and Northwest of Argentina, however the new species has a tiny but well defined preadductorial node, absent in the species of Orechina, the sulcus S2 is inconspicuous and the muscle spot is lack. Thus, the recorded material was defined as a new 
Table 2. Measurements $(\mu \mathrm{m})$ of Conchoprimitia brasiliensis $\mathrm{n} . \mathrm{sp}$. Parastratotype-section of the Vila Maria Formation, Aldeia creek, Boa Vista Farm, Bom Jardim de Goiás County, State of Goiás, central Brazil.

\begin{tabular}{cccccc}
\hline Specimen & $\mathrm{L}$ & $\mathrm{H}$ & $\mathrm{L}: \mathrm{H}$ & $\begin{array}{c}\text { Illustration } \\
\text { (Figure) }\end{array}$ & View \\
\hline $\begin{array}{c}\text { CP-631 } \\
\text { Holotype }\end{array}$ & 1300 & 914 & 1,42 & $4 \mathrm{G}$ & rigth valve \\
CP635 & 1310 & 860 & 1,52 & $4 \mathrm{I}$ & $\begin{array}{c}\text { rigth valve } \\
\text { left valve }\end{array}$ \\
CP-649 & 1303 & 743 & 1,75 & $4 \mathrm{H}$ & \\
\hline
\end{tabular}

species of Conchoprimitia. Conchoprimitia brasiliensis $\mathrm{n}$. sp. differs from C. socialis (Brøgger, 1882), type species of the genus, from the Lower to Middle Ordovician of the Baltic region, mainly by the lack of a muscle spot. Another difference is its smaller size (L reaches $4.45 \mathrm{~mm}$ in C. socialis), although this difference could be attributed to the presence of juveniles specimens only. C. socialis shows important intraspecific variations (Tinn et al., 2010), preventing the specific differentiation.

Respect to Conchoprimites osekensis Přibyl, 1979, from the Darriwilian of the Prague Basin, the new species differs in the outline hider, in its smaller size, in the dorsal position of the preadductorial node, and in the punctate lateral surface. The Polonian species C.? modlinski Olempska, 1994, C.? polonica Olempska, 1994 and C.? ventroincisurata (Hessland, 1949), differ from Conchoprimitia brasiliensis n. sp. by the outline of the valves, by the smooth surfaces and by the indistinct and short sulcus that does not reach the dorsal margin. Conchoprimitia sp., from the Middle Ordovician of Portugal (see Vannier et al., 1989), has a more elongate outline, a more inconspicuous adductorial sulcus and a smooth lateral surface.

Respect to other South American species the new material is similar to C.? iglesiasi Salas \& Vaccari, 2012 from the Floresta Formation (Tremadocian) of the northwest Argentina, however the species differs in the very inconspicuous preadductorial node and adductorial sulcus and in the smooth lateral surface. C. frecuens Salas, 2011 from the middle to upper Floian of the Acoite Formation in northwest Argentina has a subcircular outline, a rounded adductorial muscle spot, an indistinct, V-shaped and short adductorial sulcus, a rugose lateral surface and a poorly defined bend between lateral and marginal surfaces.

Occurrence. Known only from the type locality at the Aldea Creek, Boa Vista Farm, Bom Jardim de Goiás County, State of Goiás, central Brazil.

\section{BIOSTRATIGRAPHIC AND PALEOGEOGRAPHIC CONSIDERATIONS}

The knowledge of the Lower Paleozoic fauna of the Paraná Basin is scarce and patchy, and particularly the ostracods are unknown. The fossil occurrences are mostly limited by generic citations on papers, with no further investigations on their taxonomy (Popp et al., 1981; Burjack \& Popp, 1982; Faria, 1982). In this context, additional elements, such as the recorded Ostracoda of the Vila Maria Formation, might contribute to the debate regarding the age of the sequence and its paleobiogeographical affinities.

The Ostracoda species come from the lower portion shales of the parastratotype-section of the Vila Maria Formation. This mudstone interval of approximately $11 \mathrm{~m}$ thick was interpreted as a periglacial marine environment from mid to outer continental shelf (Assine et al., 1998). This is evidenced by the transitional aspect of the sequence between the glacial diamictites of Iapó Formation and the fossiliferous black shales rich in organic matter of the Vila Maria Formation. The transitional level between Iapó and Vila Maria formations is composed of a pebbly shale layer with dropstones that become scarcer toward the fossiliferous shales, and are $0.5 \mathrm{~m}$ thick. The depositional paleoenvironment of the basal shale was colonized by a benthonic and/or epibenthonic/epiplanctonic fauna consisting of Ostracoda, Mollusca and Brachiopoda, material first and partially documented by Pop et al. (1981).

The fauna shows a low diversity of species and an abundant number of specimens of each taxa, feature probably linked to the high latitudinal position of the basin and related with the latitudinal diversity gradient hypothesis as was suggested by Benedetto et al. (2013) for the brachiopod fauna of the Eusebio Ayala Formation (Paraguay).

Nearer to the top, the sedimentary rock of the Vila Maria Formation becomes coarser upwards, indicating a higher energy environmental condition. In this sandy interval of the upper portion of the Vila Maria Formation only traces of Arthrophycus alleghaniensis occur.

Arthrophycus alleghaniensis is important because mark the top of the Vila Maria Formation. A. alleghaniensis has a worldwide distribution with occurrences registered, since the Ordovician to the Silurian, in the Nhamundá Formation, early Silurian of the Amazonas Basin (Nogueira et al., 1999), lower Silurian of the Appalachian Basin, eastern USA (McCoy et al., 2012), Adigrat Sandstone, Ordovician in south-central Eritrea (Kumpulainen et al., 2006) and in the Hawaz Fornation, Ordovician of the Murzuq Basin in Al Barkat in South of Gant, Asia (Worsley, 2000). So considering this, only the occurrence of $A$. alleghaniensis is not a good dating tool, and the occurrence in the upper portion of Vila Maria Formation, cannot provide, by itself, a confident age as Silurian for this interval. In this paper, for lack of another dating element in this interval, and considering the stratigraphic correlation among other basins presented above, these sandstones will be held in the Llandovery. The facies analysis of the upper level of the Vila Maria Formation allied with the palaeoenvironmental data based on the ichnofossil occurrence allowed sketch its sub-coastal habitat under the influence of periglacial climate in the Paraná Basin, which was colonized by A. alleghaniensis in the interface between sand layers and thin lenses of silt.

Palynological content was another argument used for the previous positioning of the entire Vila Maria Formation in the Llandovery (Gray et al., 1985; Mizusaki et al., 2002). However, even if they proposed an early Silurian age for the lower levels of the Vila Maria Formation, Gray et al. (1985) and Mizusaki et al. (2002) did not record any age-diagnostic 
species in the palynological assemblage. They documented an assemblage which may indicate a Late Ordovician to early Silurian age. The authors also obtained a $\mathrm{Rb}-\mathrm{Sr}$ age for the shale levels and, as with the palynological data, they assumed an early Silurian age. However, the range in the referenced time-scales is from the Hirnantian to the Llandovery.

The ostracods documented in the present work constitute the most secure dating element that allows positioning the Vila Maria Formation in the lower Paleozoic. Until now only two species were defined, while there are at least two who still could not be identify due to the scarcity and bad preservation of valves. The recorded genera, Conchoprimitia and Satiellina, although not fully diagnostic, are up to now recorded in the Ordovician only. The eridostracan genus Conchoprimitia appeared with the earliest ostracods in the upper Tremadocian of northwestern Argentina (Salas \& Vaccari, 2012) and persisted until the Late Ordovician in the Baltic region. On the other hand, Satiellina has until now been restricted to the Middle and Upper Ordovician of IberoArmorica, North Africa and Sweden (Vannier, 1986; Vannier et al., 1989). Therefore, based on the new Ostracoda data we may assume that the age of the lower levels of the Vila Maria Formation is Late Ordovician.

With respect to the paleobiogeographical affinities, although only two Ostracoda species were recorded we can provide some preliminary considerations. Conchoprimitia is a geographically widespread genus, with a large number of known species since the Early Ordovician (Vannier et al., 1989; Olempska, 1994; Tinn et al., 2010; Salas, 2011). However, these featureless genera, with several species included in them, should be treated with caution because they could show a trend to homeomorphy and distort the real paleobiogeographical relationships (Schallreuter, 1988; Williams et al., 2003). Instead, Satiellina was recorded in the Caradoc of Ibero-Armorica (Vannier, 1986; Vanier et al., 1989), and it can also be found at approximately coeval levels of the Djeffara Formation in Libya, which would suggest a relationship between these basins.

The connection and correlation between these Brazilian and North African basins was previously suggested by Benedetto et al. (2013), based on the Hirnantian brachiopods from the Paraná Basin (Eusebio Ayala Formation) of Paraguay. In addition, the similarity is noteworthy between the lithological succession of the Rio Ivaí Group with the stratigraphic sequence of other Late Ordovician-early Silurian basins from Brazil and Northwest Africa, supporting the correlation and the dispersal pattern of the fauna. For example, the Maranhão intra-cratonic Basin in the northeast of Brazil (Grahn \& Caputo, 1992), the Ghana Basin located along the Atlantic coast of West Africa (Villeneuve, 2005), the Bové Basin in Guinea and Senegal (Villeneuve \& Da Rocha Araujo, 1984), the Hodh and Taoudeni basins in Mauritania (Underwood et al., 1998; Ghienne, 2003) and the Ghadames Basin in Libya show glaciogenic packages succeeded by frankly marine sequences of periglacial conditions as seen in the Paraná Basin. The analyzed data from the Iapó and Vila Maria formations would reflect the Hirnantian glaciation and periglacial environment and its subsequent recovery, and its correlation with the other basin in the north of Gondwana (Figure 5). However, it is a preliminary analysis and a complete study of the fauna will be necessary to approach a deeper paleoecological and paleogeographic study of the sequence.

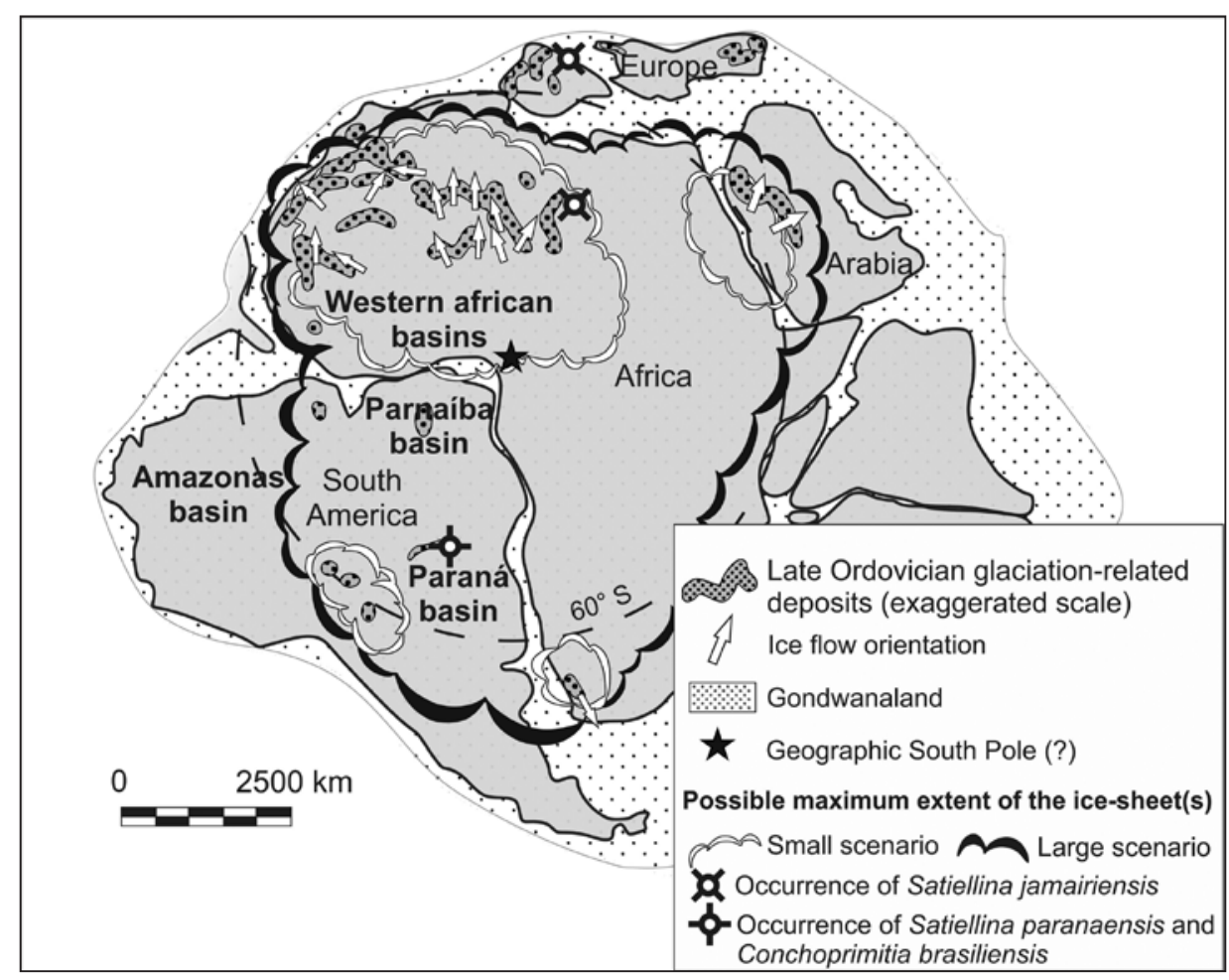

Figure 5. Paleogeographic reconstruction showing the occurrences of identified Ostracoda species and the extent and flow direction of existing glaciers during the Late Ordovician (Adapted from Ghienne, 2003). 


\section{CONCLUSIONS}

Upper Ordovician Ostracoda from Brazil are described in detail for the first time, and constitute the record of the earliest Ostracoda fauna from Brazilian strata. The fauna is recorded in the lower levels of the Vila Maria Formation in the Paraná Basin. Until now the diversity of the recorded fauna has been low, with only two species described. Both species are new: Satiellina paranaensis n. sp. and Conchoprimitia brasiliensis $\mathrm{n}$. $\mathrm{sp}$. Based on the Ostracoda fauna, a Late Ordovician age was suggested, instead of the early Silurian previously proposed for the whole Vila Maria Formation based on Arthrophycus alleghaniensis. On the other hand, the presence of Satiellina indicates a paleobiogeographic affinity with the basins in the north of Africa, which together with the stratigraphic similarities would suggest a connection between the intra-cratonic basins of the north of South America and the north of Africa as was previously suggest by the brachiopod fauna described by Benedetto et al., 2013. However, a deeper analysis of the whole fauna is necessary for a better knowledge of the studied sequences.

In addition to the paleontological, stratigraphic and paleogeographic data from the Vila Maria Formation, the cartographic information regarding the type-locality and parastratotype-locality of the Vila Maria Formation was updated, as well as other key-localities of this interval on the northern border of the Paraná Basin.

\section{ACKNOWLEDGEMENTS}

The authors are grateful to the Museum of Geosciences for housing the illustrated material. To CICTERRA - CONICET, Universidad Nacional de Córdoba, Argentina, for assigning the space and equipment to study the fossil material. To CNPq and FUB/FINATEC for the financial support and PETROBRAS/ ANP for granting the OSTRAKi project. M.L.A thanks CNPq for research grant 459776-2014-2 and scholarship PQ. All authors are grateful, as well, to the Microprobe Laboratory of the Institute of Geosciences, and the Laboratory of Electron Microscopy, Institute of Biological Sciences, University of Brasilia, for the metallization and imaging services of the illustrated materials. To the University of Brasília for call DPP-1/2014 for supporting publications. To researchers E.M. Guimarães, C.J. Abreu and CJ.S. Alvarenga and especially to Á. Faria for participation in field trips and their contribution.

\section{REFERENCES}

Adamczak, F. 1961. Eridostraca a new suborder of ostracods and its phylogenetic significance. Acta Palaeontologica Polonica, 6:29-102.

Adôrno, R.R. 2014. Estudo cronobioestratigráfico da Formação Vila Maria: litoestratigrafia e paleontologia do limite OrdovicianoSiluriano da Bacia do Paraná, estados de Goiás e de Mato Grosso, Brasil Central. Programa de Pós-Graduação em Geologia, Universidade de Brasília, M.Sc. thesis, 84 p.

Alvarenga, C.J.S.; Guimarães, E.M.; Assine, M.L.; Perinotto, A.J. \& Laranjeira, N.P.F. 1998. Seqüências Ordovício-Siluriana e Devoniana no flanco norte da bacia do Paraná. Anais da Academia Brasileira de Ciências, 70:587-606.

Assine, M.L.; Alvarenga, C.J.S. \& Perinotto, J.A.J. 1998. Formação Iapó: glaciação continental no limite Ordoviciano/Siluriano da Bacia do Paraná. Revista Brasileira de Geociências, 28:51-60.

Assine, M.L. \& Soares, P.C. 1989. Correlações nas sequências mesopaleozóicas da Bacia do Paraná. Acta Geológica Leopoldensia, 29:39-48.

Assine, M.L.; Soares, P.C. \& Milani, E.J. 1994. Sequências tectonosedimentares mesopaleozóicas do Paraná, sul do Brasil. Revista Brasileira de Geociências, 24:77-89.

Benedetto, J.L.; Halpern, K. \& Inchausti, J.C.G. 2013. High-latitude Hirnantian (latest Ordovician) brachiopods from the Eusebio Ayala Formation of Paraguay, Parana Basin. Palaeontology, 56:61-78. doi:10.1111/j.1475-4983.2012.01158.x

Borghi, L.; Moreira, I.C. \& Fernandes, A.C.S. 1996. A ocorrência do icnogênero Arthrophycus Hall, 1852 em Chapada dos Guimarães, Estado de Mato Grosso. Anais da Academia Brasileira de Ciências, 68:274-275.

Brøgger, W.C. 1882. Die Silurischen etangen 2 und $3 \mathrm{im}$ Kristianiagebiet und auf Eker, ihre gliederung, fossilien, schichtenstörungen und contactmetamorphosen. Oslo, Universität programm, $376 \mathrm{p}$.

Burjack, M.I \& Popp, M.T.B. 1981. A ocorrência do icnogênero Arthrophycus no Paleozóico da bacia do Paraná. Pesquisas, 14:163-167.

El-Ghali, M.A.K. 2005. Depositional environments and sequence stratigraphy of paralic glacial, paraglacial and postglacial Upper Ordovician siliciclastic deposits in the Murzuq Basin, SW Libya. Sedimentary Geology, 177:145-173. doi:10.1016/j. sedgeo.2005.02.006

Faria, A. 1982. Formação Vila Maria - nova unidade litoestratigráfica siluriana da Bacia do Paraná. Revista Ciências da Terra, 3:12-15.

Faria, A. \& Reis Neto, J.M. 1978. Nova unidade litoestratigráfica préFurnas no sudoeste de Goiás. In: CONGRESSO BRASILEIRO DE GEOLOGIA, 30, 1978. Resumo das Comunicações, Recife, p. 136-137.

Ghienne, J.F. 2003. Late Ordovician sedimentary environments, glacial cycles, and post-glacial transgression in the Taoudeni Basin, West Africa. Palaeogeography, Palaeoclimatology, Palaeoecology, 189:117-145. doi:10.1016/S00310182(02)00635-1

Grahn, Y. \& Caputo, M.V. 1992. Early Silurian glaciations in Brazil. Palaeogeography, Palaeoclimatology, Palaeoecology, 99:9-15. doi:10.1016/0031-0182(92)90003-N

Gray, J.; Colbath, G.K.; Faria, A.; Boucot, A.J. \& Rohr, D.M. 1985. Silurian-age fossils from the Paleozoic Paraná Basin, Southern Brazil. Geology, 13:521-525. doi:10.1130/0091-7613(1985) 13<521:SFFTPP $>2$.0.CO;2

Hall, J. 1852. Palaeontology of New York containing descriptions of the organic remains of lower Middle Division of the NewYork System (equivalent in part to the Middle Silurian rocks of Europe). Albany, C. van Benthuysen, 358 p.

Harlan, R. 1831. Description of an extinct species of fossil vegetable, of the family Fucoides. Journal of the Academy of Natural Sciences of Philadelphia, 6:289-295.

Henningsmoen, G. 1953. Classification of Paleozoic straight-hinged ostracods. Norsk Geologisk Tidsskrift, 31:185-288.

Hessland, I. 1949. Investigations of the Lower Ordovician of the Siljan District, Sweden, I. Lower Ordovician Ostracodes of the Siljan District. The Bulletin of the Geological Institution of Uppsala, 33:97-408. 
Krůta, M. 1968. Orechina n. g. (Ostracoda, Crustacea) from the Upper Ordovician of Bohemia. Časopis pro mineralogii a geologii, 13:55-62.

Kumpulainen, R.A.; Uchman, A.; Woldehaimanot, B.; Kreuser, 1.T. \& Ghirmay, S. 2006. Trace fossil evidence from the Adigrat Sandstone for an Ordovician glaciation in Eritrea, NE Africa. Journal of African Earth Sciences, 45:408-420. doi:10.1016/j. jafrearsci.2006.03.011

Lajblová, K.; Krafta, P. \& Meidla, T. 2014. Ontogeny of the ostracod Conchoprimitia osekensis (Přibyl, 1979) from the Darriwilian of the Prague Basin (Czech Republic). Estonian Journal of Earth Sciences, 63:144-155. doi:10.3176/earth.2014.13

Latreille, P.A. 1802. Histoire naturelle, générale et particulière, des crustacés et des insectes. Tome 3, familles naturelles des genres. Paris, Dufart, $467 \mathrm{p}$.

McCoy, V.E.; Strother, P. K. \& Briggs, D. E. G. 2012. A possible tracemaker for Arthrophycus alleghaniensis. Journal of Paleontology, 86: 996-1001. doi:10.1666/11-133R1.1

Milani, E. J.; França, A.B. \& Schneider, R.L. 1994. Bacia do Paraná. Boletim de Geociências da Petrobras, 8:69-82.

Milani, E.J.; Melo, J.H.G.; Souza, P.A.; Fernandes, L.A. \& França, A.B. 2007. A Bacia do Paraná. Boletim Geociências da Petrobras, 15:265-287.

Mizusaki, A.M.P.; Melo, J.H.G.; Vignol-Lelarge, M.L. \& Steemans, P. 2002. Vila Maria Formation (Silurian, Paraná Basin, Brazil): integrated radiometric and palynological age determinations. Geological Magazine, 139:453-463. doi:10.1017/S0016756802006659

Mohibullah, M.; Williams M. \& Zalasiewicz, J. 2014. Late Ordovician ostracods of the Girvan district, south-west Scotland. London, Palaeontographical Society, 40 p. (Monograph 167).

Moore, R.C. \& Pitrat, C.W. 1961. Treatise on invertebrate Paleontology, part Q. Arthropoda, 3, Crustacea, Ostracoda. Lawrence, Geological Society of America and University of Kansas Press, 442 p.

Nogueira, A.C.R.; Truckenbrodt, W. \& Soares, E.A.A. 1999. O icnogênero Arthrophycus de depósitos sublitorâneos da Formação Nhamundá (Siluriano Inferior) da Bacia do Amazonas, região de Presidente Figueiredo. Revista Brasileira de Geociências, 29:135-140.

Olempska, E. 1994. Ostracods of the Mójcza Limestone. Paleontologia Polonica, 53:129-212.

Öpik, A.A. 1935. Ostracoda from the lower Ordovician Megalaspislimestone of Estonia and Russia. Annales of the Naturalists Society of Tartu University, 42:28-38.

Pokorný, V. 1954. A contribution to the taxonomy of the Paleozoic ostracods. Sbornik ústředniho ústavu geologickeho (oddíl paleontologický), 20:213-232.

Popp, M.T.B.; Burjack, M I. \& Esteves, L.R. 1981. Estudo preliminar sobre o conteúdo paleontológico da Formação Vila Maria (préDevoniano) da Bacia do Paraná. Pesquisas, 14:169-180.

Přibyl,A. 1979. Ostrakoden der. árka. bis Králův Dvůrschichtengruppe des böhmischen Ordoviziums. Sborník Národního Muzea, Rada $B, 33: 53-145$.

Rong, J.Y. \& Harper, D.A.T. 1988. A global synthesis of the latest Ordovician Hirnantian brachiopod faunas. Philosophical Transactions of the Royal Society. Earth Science, 79:383-402.

Rubino, J.L.; Deynoux, M.; Ghienne, J.F.; Moreau, J.; Blanpied, C.; Lafont, F.; Andres-Calatrava, R.; Galeazzi, S.; Mynth, T. \& Sommer, F. 2003. Late Ordovician glaciation in northern Gondwana, reappraisal and petroleum implications. In: AAPG HEDBERG CONFERENCE, 2003. Abstracts, Algiers, p. 1-4.
Salas, M.J. 2011. Early Ordovician (Floian) ostracods from the Cordillera Oriental, Northwest Argentina. Geological Journal, 46:637-650. doi:10.1002/gj.1319

Salas, M.J. \& Vaccari, N.E. 2012. New insights into the early diversification of the Ostracoda: Tremadocian ostracods from the Cordillera Oriental, Argentina. Acta Palaeontologica Polonica, 57:175-190. doi:10.4202/app.2009.1110.

Sars, G.O. 1866. Oversight af Norges marine ostracoder. Forhandlinger $i$ Videnskabs-Selskabet i Chtistiania, 1865:1-130.

Schallreuter, R. 1972. Drepanellacea (Ostracoda, Beyrichicopida) aus mittelordovizischen Backsteinkalkgeschieben IV. Laterophores hystrix sp. n., Pedomphalella germanica sp. n. und Easchmidtella fragosa (Neckaja). Berichte der Deutschen Gesellschaft für Geologische Wissenschaften A, 17:139-145.

Schallreuter, R. 1988. Homeomorphy, phylogeny and natural classification: case studies involving Palaeozoic ostracods. Developments in palaeontology and stratigraphy, 11:1041-1049.

Tinn, O.; Meidla, T. \& Sohar, K. 2010. Intraspecific variation and polymorphism in the ostracode Conchoprimitia socialis (Brøgger, 1882) from the early Middle Ordovician Baltoscandian Palaeobasin. Bulletin of Geosciences, 85:603-616. doi:10.3140/ bull.geosci.1183

Ulrich, E.O. \& Bassler, R.S. 1923. Paleozoic Ostracoda: their morphology, classification and ocurrence. In: Mathews, E.B. (ed.) Maryland Geological Survey, Silurian, The Johns Hopkins Press, p. 271-391.

Underwood, C.J.; Deynoux, Ł.M. \& Ghienne, J.F. 1998. High palaeolatitude (Hodh, Mauritania) recovery of graptolite faunas after the Hirnantian (end Ordovician) extinction event. Palaeogeography, Palaeoclimatology, Palaeoecology, 142:91105. doi:10.1016/S0031-0182(98)00070-4

Vannier, J.M.C. 1983: On Bollia delgadoi Vannier sp. nov. Stereo atlas ostracod shells, 10:95-98.

Vannier, J.M.C. 1986. Ostracodes Palaeocopa de l'Ordovicien (ArenigCaradoc) Ibero-Armoricain. Palaeontographica, 193:145-218.

Vannier, J.; Siveter, D. \& Schallreuter, R. 1989. The composition and palaeogeographical significance of the Ordovician ostracode faunas of Southern Britain, Baltoscandia and Ibero-Armorica. Palaeontology, 32:163-222.

Villeneuve, M. 2005. Paleozoic basins in West Africa and the Mauritanide thrust belt. Journal of African Earth Sciences, 43:166-195. doi:10.1016/j.jafrearsci.2005.07.012

Villeneuve, M. \& Da-Rocha-Araújo, P.R. 1984. Lithostratigraphie du bassin paléozoïque de Guinee (Afrique de l'Ouest). Bulletin Société géologique de France, 7:1033-1039. doi:10.2113/ gssgfbull.S7-XXVI.6.1033

Williams, M.; Floyd, J.D.; Salas, M.J.; Siveter, D.J.; Stone, P. \& Vannier, J.M.C. 2003. Patterns of ostracod migration for the 'North Atlantic' region during the Ordovician. Palaeogeography, Palaeoclimatology, Palaeoecology, 195:193-228. doi:10.1016/ S0031-0182(03)00308-0

Worsley, D. 2000. Geological exploration in Murzuq Basin Amsterdan, Elsevier, 534 p.

Zabini, C.; Adôrno, R.R.; Do Carmo, D.A. \& Assine, M.L. 2016. Juvenile Kosoidea sp. from Lower Paleozoic strata, Paraná Basin, Brazil. In: INTERNACIONAL GEOLOGICAL CONGRESS, 35, 2016. Poster Abstracts, Cape Town.

Zalán, P.V.; Wolff, S.; Conceição, J.C.J.; Vieira, I.S.; Astolfi, M.A.M.; Appi, V.T. \& Zanotto, O.A. 1987. A divisão tripartite do Siluriano da Bacia do Paraná. Revista Brasileira de Geociências, 17:242-252.

Received in May, 2016; accepted in October, 2016. 